This report was prepared as an account of work sponsored by an agency of the United States Government. Neither the United States Government nor any agency thereof, nor any of their employees, makes any warranty, express or implied, or assumes any legal liability or responsibility for the accuracy, completeness, or usefulness of any information, apparatus, product, or process disclosed, or represents that its use would not infringe privately owned rights. Reference herein to any specific commercial product, process, or service by trade name, trademark, manufacturer, or otherwise does not necessarily constitute or imply its endorsement, recommendation, or favoring by the United States Government or any agency thereof. The views and opinions of authors expressed herein do not necessarily state or reflect those of the United States Government or any agency thereof.

\title{
Cover Sheet for a Hanford Historical Document Released for Public Availability
}

Released 1994

Prepared for the U.S. Department of Energy under Contract DE-AC06-76RLO 1830

Pacific Northwest Laboratory

Operated for the U.S. Department of Energy

by Battelle Memorial Institute
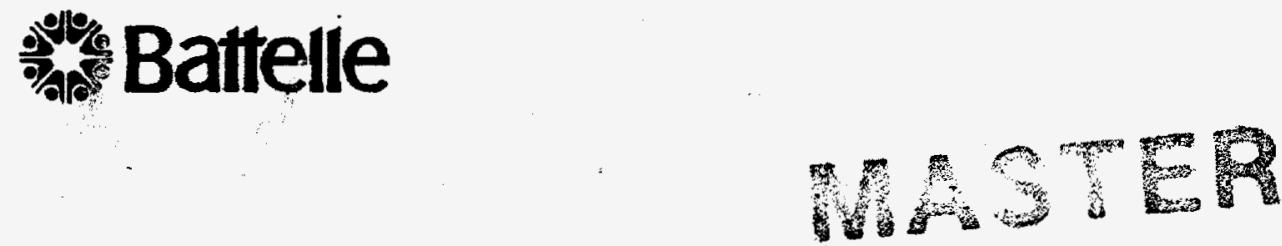


\section{DISCLAIMER}

Portions of this document may be illegible in electronic image products. Images are produced from the best available original document. 
Route List.

1.

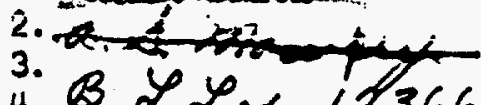

4. B. L. L. 17/366 7/39

5. J.B.FECHT $236-7134$ G.N.zenderward 12956
Doni23
FILE \&twe $20 d \%$

DATE 28,290

SUQUECT Inalliting

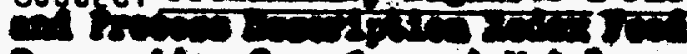

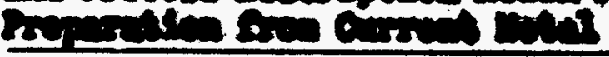

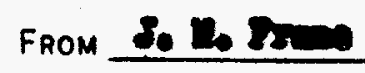

Copr No.

BEFORE REAOING THIS DOCUNENT. SIGN ANO DATE BELOW:

5K.2-5311 ditached

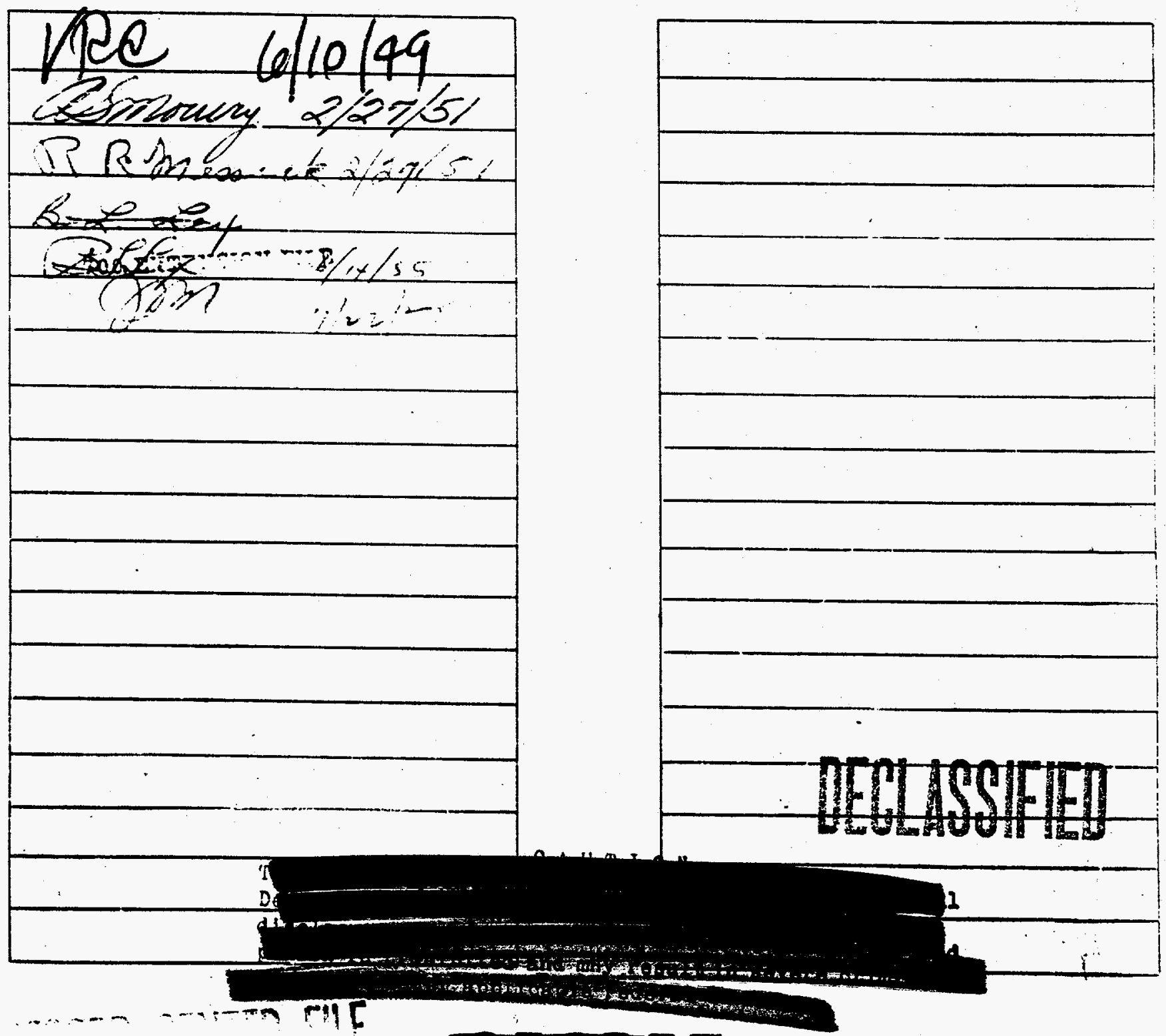




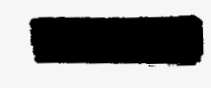

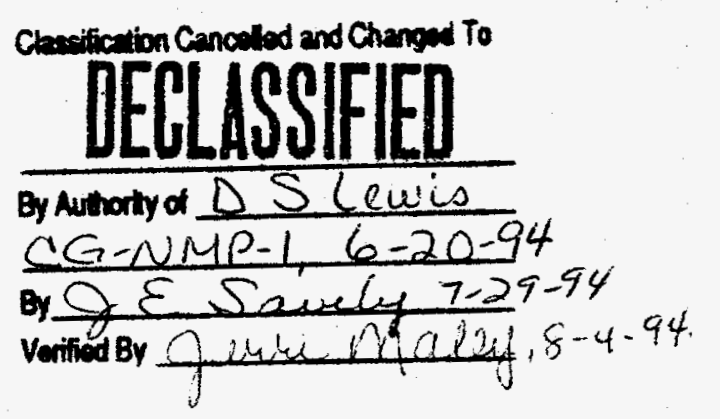

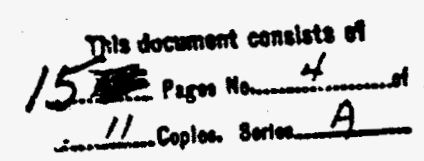

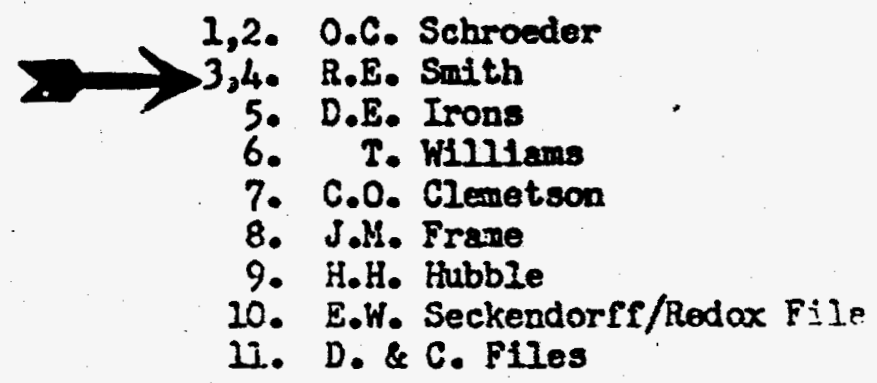

May 27, 1949

D) File

FROK: J. N. Frame

PRELIMINARY ENGINEER'S FLOY SKETCH AND PROCESS DESCRIPTION

REDOX FEED PREFARATION FROY CUKRENI METAL

Project: C-187-D - Medox Production Plant No. 1

Prepared by: H. E. Hanthora

$-1-$

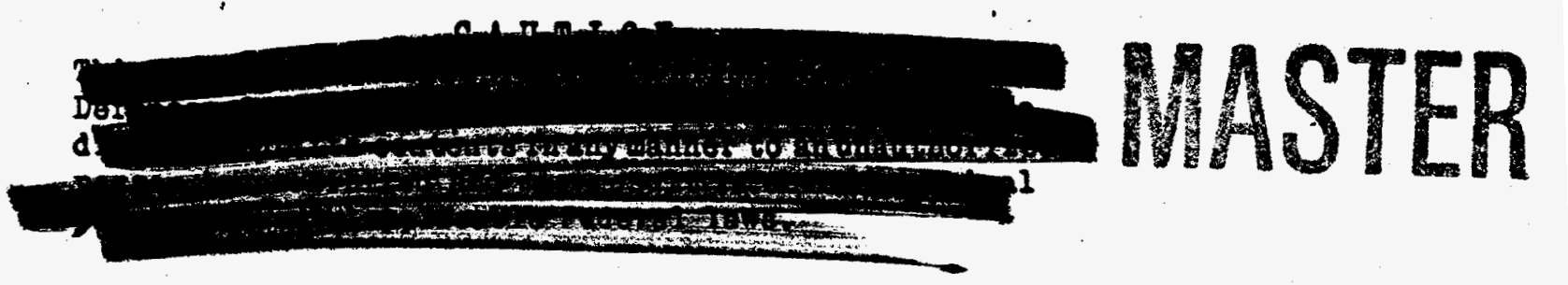




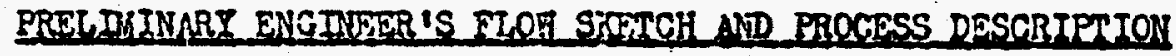

REDOX FEDD PREPARATION FROH CURPENT UETAT

\section{INTRODUCTTON}

The basis foed to the Redox plant is 5,000 Ib/das of urantur, supplied both as current irradiated uranium metal slugs in jackets, axd as uranium compounds from the existing metal rasto storage tanks. The proportions of the tro feedis are chosen according to the enriohwent Iovel of the Irradiated metal, so as to give a plutonium production of about $650 \mathrm{gm} / \mathrm{dag}$. The design basis has been taken as 0 to $1500 \mathrm{Ib} / \mathrm{day}$ U from the waste storago aystem and 2000-5000 1b/dar of Irradlated Intal. Only the feed proparation fron irradiated motal is discussed In this piocess description, and a basis of 5000 1b/day is used throughout.

The metel feed has assoclated with it $172.5 \mathrm{lb}$. Al and 2.5 1b. S1 as alus jackits, and contsins about $650 \mathrm{gm}$. plutonium and

. 3r 105 curles of gama-enitting fission products.

The purpose of the feed preparation section is to remoto the aivmimm and silicon, and to dissolve the urantum as an aqueous solution for feed to the Redox extraction battery. Secopidarily, it is tentatively proposed to prorlds equipment in this seotion to ableve a preliminary decontanination from rutheniwe, which is poorly handled by the Redoc extraction aystew, and Srom IP whoh are adsorbed by the fliterald used in the clarifleation step.

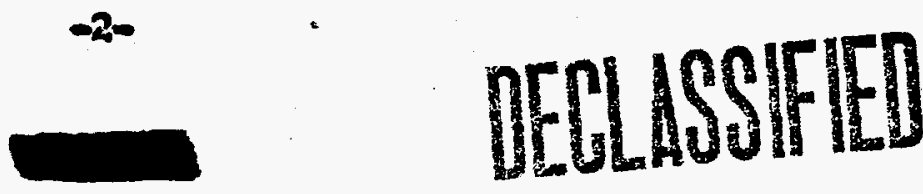


th-2237

The prodact of the foed proparation section is an aqueous solution of urang). nitrate hescabpdrate of $59.4 \%$ (2 U) concontration, With part of the stoichiometrio nitrate lon neutralized by naoti, and contaluing pearly $2 \%$ sodium dichromato as an oxldising agent. It contains $99.9+\%$ of the plutonium originally ingithe slugs, and pertatos 28 11ttIo as $0.3 \times 10^{5}$ curles of gamnamenitting PP.

\section{PROGESS. OUTLTIS}

\section{Remorel of fackets and dissolving}

Jecketed Irradiated slugs are recelved from the 200-il area In buoketo in casis cars as at present. Pivo buokets, oach containing 255 ajugs, constitute a basis charge. (Elght such buckets constitute a maxtmun charge as discussed belot.) The slugs are charged to the dissolver as at present. Tho fackets are then removed by the following prosedure: 3208 1b. $26 \%$ sodiun nitrate is run into the dissolver. Thon 892 Ib. $50 \%$ sodium hydroxide 1s added at a controlled rate, with sufficient sten on the dissolver coll to cause bolling. Bolling is contimed for tro hr, then cooling rater is run into the coll and the charge cooled to $40^{\circ} \mathrm{C}$. for jotting to the waste bold tank. A water rash of 696 Ib., followed by a 5\% nftrlc acid wash of 3583 Ib., Ia addod and fetted to raste concentrat10n. D18solving aold is then added 20 portions of 4083 2b. $60 \% \mathrm{HNO}_{3}$ each; if the altrio aold oupplied to tho plant $1068 \%$ strength, it can be roduoed it the welgh tank before adding to the dissolver, or the water for roduction ner bo used as tapk Flose. Stean 18 run to the dissolves coll as reo quired to start the react10n, reduced (or cooling wtor applied) to control the rate, and reapplied to sintob tho cut, as in present practice. 
BDC-1237

The out 18 complete when the speoleso gravity of the solution at the bolling point (about 109\%) reaches 1.82. Tho sointion 18 cooted to $60^{\circ} 0$ and gotted to the motal solution tank. Three cuts as desoribed complete the dissolution of a basis chargo. Ho dilution inrtbe dissolver is assumed, since ang water added at thls polot would have to Do ovaporatod at a later stago. F. Hollenbach otates that 1 is posesble to jot concentratod ONH solutione at $600^{\circ}$, and sceesing polut curres ahow that the solution will not freeze above $35^{\circ}$.

The dissolver off-gases aro passed into a combabar, wherein thog are corrubbed with a solution marly saturated wh $\mathrm{NaHO}_{3}$ and $\mathrm{NaNO}_{2}$ and containing $\mathrm{NaOH}$ surficiont to absorb all of the ocides of nitrogen entering. It is esswed that a scrubber designod on this bas1: all gite reasonable absorption of radiolodiso. The operation of the sorubber is as described in EDC-886, afth plo oontrol of the scrubbar effluent. The scrubber offluent flows direotls to rasto storage, since it 18 extremely unlluels that aw of or Pu values could find thols was lato this strean. It mas be noted that if the only actifity in the serubber effluent is 2 131 , this stream could be conomically disposed of by routing it to a separate tank cascade, Ith a holdup of about 150 dase minimen, and with overnlow frow the final tank to orib. The als leaving the scrubber passes through a glass w001 capsule and thence to the stack, neing a int as peime morver.

Tho throo cuts constituting a basls obarge as decoribed above are all received in one notal solution storage tank and blended tborvin, in order to maintain a foed straam of as mifocm pitutonim 20 
BDC-1237

concentration as possiblo. The metel solution tanke should bere capecity for 10,000 Ib metel as dissolvar solution (two basis charges) in arder to provide a reserrois af foed for perlods in which the reather is unsatisfactory for dissolving. For the ano H. . . . reason, the actual operation of the dis801vers ahourd be with 8000 Ib oharges, the narsimm of whioh they are capabie, Instead of the bado aharge as shown abore.

\section{Oxdation and clarification}

Vetal solution is whitram fron the metal colution storago tanks in oufficlent quantity for a day's operation of the Redox extrection battery, to the oxidizer, and is there anmplod for critical mess control and Froo aoldity. Oxldant solution, 626 Ib $50 \%$ sodim dichromate dingrate solution, is added, the solution is beated to $95^{\circ} \mathrm{C}$, and hold for $6 \mathrm{hr}$. During this period it 18 tentatively proposed that 200 chm of 28 ozonlzed als be sparged 10to tho oxtdizer. A large part of the rutheniun would bo oxidized to $\mathrm{RnO}_{4}$ by this procodure, and rolat1lized and swept out of the oxddizer by the atr. Ang Il31 not remored in the diseslring step world also be swept our at this point. Tho alr leaving thoioxidizer would oary about $5531 \mathrm{Ib} / \mathrm{daj}$ of weter vapor, this would have to be reflusood by a condensor in a colum similar to the arrangement on the dissolver, or the rutbonium serubber would have to bo operated at about $100^{\circ} \mathrm{C}$ If roflexing ahould cerry back quantitlos of the volat1le IP belng errolved

Ibs alr, oarying the rutbonim and 10dive, passes to $a$ canstie scrubber, Wh10h removes the 78 . The sorabber is operated at 
400-1237

room tomperatoro ualess rafluding in tho oxdalsor is not foastbio, In which case the temperature will be about $200^{\circ} \mathrm{C}$, and a surface condensar will be added following the scrubber, the dlochargt of whiob Fill bo routed to the condensate heodor. The atr then passes tirrough a capante of glass rool, and thopce to the stack Vla a jet ad profme mover.

\section{1,3}

Fallowing the oxidation, 279.5 superplltrol is added as a soavenger for tine "arudi to be renoved by centrirugation. The fliterald is wafghed into a buckst, and dugped by crane into a chato, from thich it fallo into tho oxidiser. Neter rinsing was be omployed if neceseary; to transfer the filterald cleanly. The filterald is thon rell auspended in the solution by agitation; the charge is then fotted at a controlled rate to a 40 in solid bovl centrifuge, sintlar to the machines in use in the ecisting plant. The clarifled solution Nlow to the IUP makeup tank, the fllteraid and "crud" boing rotained in the contrifuge boxl. When the charge is all centrifuged, the boul holdup Is rechuced to $35 \mathrm{gal}$ Fith the aximmer. The caice is thon slury wasbed three times, first with $50 \mathrm{gal}$. water, then turlce with $50 \mathrm{gal}$. 18 nitrio ec1d. The dilute acld mashes are expected to olute the adsorbed plutonium without romoring the adsorbed FP. Pinally, the cake is alurried out of the bowl with water or acid to the clings bold tank, where it is sampled and anelgzed for total alphe. If the

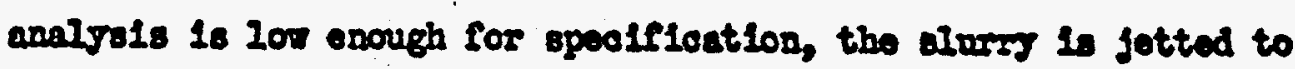
the waste neutralizer, if not, it is soturned to the coddizar for surther treatment.

$$
6
$$

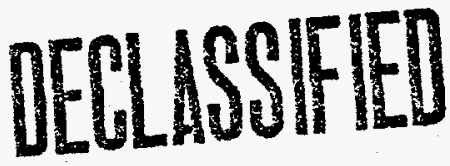


4DC-1237

\section{Aciditr and concentration ediugtment}

Final adjustment of the acidity and the concentration of the feed solution 18 made in the IUP makeup tank. Fron the results of the free acialty determination on the senple taken in the coldisar, the weight of nitrio acid in the batch is computed. Raod equivalent to this weight, plus 84.6 Ib cxtra HaOH (sbown on the Flow Sketeh wo 133.2 1b. negat170 acidity) 1s added as a 50,3 colution witb agltation. The Flow Siretch shors adjustwent of concentration by eraporation of excess water from the IAP makenp tank. If the alternste mothod of operation of the ruthonium scrubber notod above 1s chosen, wth no refluc from the oxidizer, and with tho scrubber temperature 10000, adjustment would always be made by dilution in the IAF makeup tank, and the reflux column and condenser for distillate ahom on the FIor Skotoh would be elininated. DISCUSSTON OF THE DESTGN

The design presented in the Englneer's Flor Sketah 5K-2-5311 is besed on recomnendations of the Technical Divisions es prosented by R. E. Silth in a rough draft entitled "Feod Preparation Floxsheot". uinor variations introctuced by the ropter in the materlal balanoes Inolude use of a littlo less nitrie ecld for alssolving, in aocondance Ith prosent plant pract1ce, dissolving to a alightly higher opectelo gravity solut10n, also present plant practice, and collosion of the dilution water from the dissolver, on the assurance of ign division personel thet the colution can be jetted at 60\%C. Ibs procechrre fos washing the filteraid in tho conterfuge was also versed, sing 


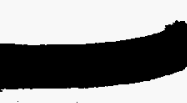

EDC-1231

displacement washiag on a solsd bowl centrifuge is not poselbio.

Hatertels to be recelived from Aqueous Hakeup (ST-2-5310) ares

2. $40 \%$ sodiun hydroside solution. Tankage in the equeous makeup soction can bo ocheduled for this solution, which is a contimouse foed. It cen be alsed in the food tank from $50 \% \mathrm{NaOH}$ and water, if desired at a later stago in the design, by the addition of an egitator.

2. $26 \%$ sodium nitrate solution. This solution is made up by dissolving a solid, bence wust bo made up in the aqueous makeup soction.

3. 50 sodium dichromate dihydrate solution. Same as 2.

4. $50 \%$ sodiun sodroxtde solution. Roceivod on the plant and transmitted to this section Fia beader.

5. $60 x$ (or 68x) nitric ac1d solution. Samo as 4.

6. 61.77 alumimun nitrate nonahydrate solution, or sodium aluminate solution. Shom on the Nowaboet in apticipation of a flowsheet change. If used, olther will bo recelved from the aqueous makeup section becanse it is made up by dissoloing a ool1d.

Other conoentrations of nftrio actd used cen bo made up in this section from $60 \%$ (or 68\%) nitrio aold and water.

Supply tankage provided Inalodes one amall and ono large walgh

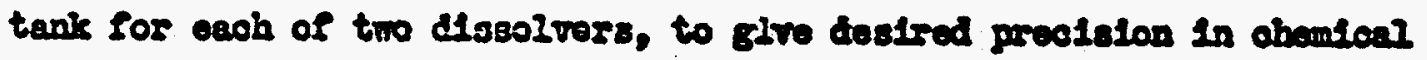
additions, and to avold echodusing difficultios and paestble arrors which might occur if one get of wolgh tanks were manffolded to all dissolrers. 
EDC-1237

For the same reason, the cosdiser and IN mboup tanks are provided with exparato wigh taskes.

Each dissolves off-gas ecrubber is sbown as haviog lte orm $40 ; 5$ IaOH oupply tank. Thls is not ossential, one supply tank and manifoldIng to the oupply pumps being equalis applicaste if desired. Tho the scrubber is shown as having no supply tank, roceiving its cantio supply diroctif from the hoaders rla metors. The oenctio is diluted with

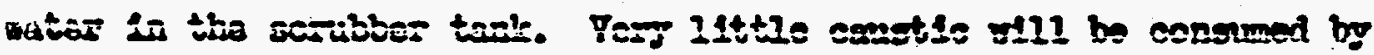
the Ru scribber, $\infty$ no weight Input has been shown on the Flor Stretch. The batah is fotted to the rasto noutraliser and forms a part of the canstie shown ontering this vessel on SK-2-5318.

Two dissolvers are shown, each conneoted to a motal solution Giorage task. Analfsis of dis3olver down time by 0. C. Schrooder proves, however, that only apjraclmately half of the total time areraged over a year is arailable for dissolving if the HI wite of weather conditlons giving a dilution factor of 1000 is adbered to. This rule mar bo relaxed after observation of off-gas decontanination by tbo canstio sorubbers, but no quantitative information upon which to requeat an imodiate if ruling is aratlable. Onder those ofrounstances, tio dissolvers will barely carry the Redox plant 10ad, oven if operated with meximm (8000 1b) charges, vith no factor for additional plant domn time. It is tharefore proposed to provide a thind dissolver, not sbom on tho Engibear's ILor Sketch, wanffolded to the welgh tanks of discolvor No. 2, and with off-gas ralved to tho lin scrubber. Since the thind disealver would be used only intermittentrf if at all, it is felt that 
EDC-1237

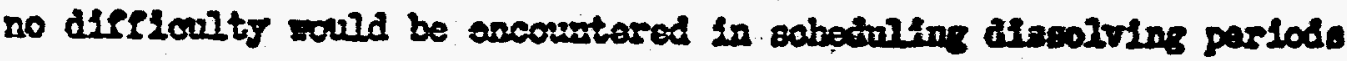
so they would not conflict mith the oxldizer.

A dissolver waste boldup tank is provided to recolve the jacket removel waste, in order that dissolver operations wa be ree frow the requirenent of oloso ochoduling with waste noutrallsetion.

In order to provide a reserpols of feed for the plant in perlods of unfararable dissolving meathor, it is proposed to provide three motal solution tenks, each with a capaoity of 10,000 1b. ureniw as dissolvor solution, a total of 6 daje besis foed. Bach of these Fill recelve from one dissolver, but thes will be Interconnected by fet Iines in order to enable a full inventory af solution to be carried at all times without the necessity of ruming the thind dissolver.

The oxddizer is similar to the diseolvers in desifn, except that tho sollda charge hopper is nocked dom to a pipe and ralred, in order to prevent oplashing of active colutlons up into the part of the bopper contacted by the Superfiltrol charging bucket. Nolghing the Superfiltrol into the broicet vill in art case be a SiP job, it is feared. The plpe through which the superfiltrol entera tho oridiser is Fignellzed as of fak-2y largo stas (8" or 10n) and equipped with a plug cock with hodrawlio or eloctrio drive, and with an emergenoy impaot mronch operator. Rinsing doin the hoppor and pipe Iine with water mas or pot bo nocessarys allowing for some rinse water is show on the BIOW Skotoh. Haintaining an atr flow through the oharging bopper with the off-ges jet and poselbif providing a vibrator on the 


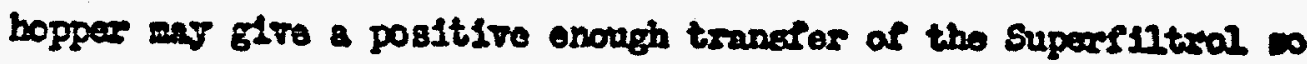
that risoing whl bo unnecossary.

If oscnation of the solution during coldation is finall sdopted, the effectiveness of a 15 osone strean should be coupared Wth that of the presently proposed 25 ozones commorolal osonisers are wach Iess officient at conoentrutions above Iff aw beth lezos oquipwout and higher electrical $100 d s$ will be required for the as 0sono stream.

Mang serious process feastbillty questions oenter on the use of Suparfiltrol (or ang insoluble filteraid) in the foed proo paration process. The transfer of the slurry from the oxidiser to the centrifuge at a controlled rate afiers the opportunity for jot IInes to plug; elurrying out the centrifuge cake appears to be very doubtfol with ouch a heavg materiol; washing the cake in the centrinfuge seens of dublous efficlency and offers the posalbility of roentraining the "crud" owot dow by the filterald on fir at centrifugation; performance of the sempler on this hasty alurey seems fraught with possibilities of plugging of IInes, otc. The eolsd bonl oentr lfugo does not appear to bo an entirely practioel tool for the purpose cs asparating and reshing the rllteraid, got embarkatlan at the present time on an oquipwent developwent progrem on a periorate boul contrifugo seems impractical. It 1s suggested that furthor attention bo glven to the use of manganose diondde, farmed in stitn. as the scavenger at this point. Ifter contrifugation is complote, it can be diseolved in the contrifuge boil with byorogen parodde and nitelo coid, and roediry Inahed out to waste. 
A slurry bold tenk is provided from which to sampite the filtarasd alurry and to eliminate tho nocessits for alose soboduring botween the ocddizer and the raste peutralizer.

The IAT makeup tank serres ss a centrifuge oatch tank, an oraporitor for adjustment of concentration, and an aftatod ressel for final adfustment of $\mathrm{pl}$. Note, bomever, in the discussion above, that provision for conoentration at this point will not bo mode if osonation without reflux is a requisite step earlier in the process.

All stream polumes show are actual dally ralumes, on the 5000 1b. uranium basis. The tank porking volumes shom are for an 8000 Ib. uraniun basts for the dissolvars and 10,000 1b. uranium basis for the motel solution tanks, and 5000 Ib. uranium basis for the subsequent process steps.

On all tanicage rolumes, heat transfer surfaces, and the like firod oquipment, with the exseption of the dissolvors and their aocessorles which aro alreads stred at a maxdmin, factors of 1.2 for dow time and 2.1 for freeboard in unagitated tanks, or 1.25 for froeboard In agltated, aparged, or bolled tanks, aro applied to resol the final tank working volume, beat transfer surface, or the Illko.

Uaterlals to be transforred to faste Ireatment and Storage $(s k-2-5318)$ ares

2. Jacket sonoval waste! transiarred to wasto neutrelizer at a point in its oyolo when the $\mathrm{NaOH}$ concentration is not 80 high that the sodium aluminate will bo proeipltated.

2. D1ssolver rinsess transferred to the rasto craporator. $-12-$ 
EDC-1237

3. Off-gen serubber wastel transferred directly to rate otorage.

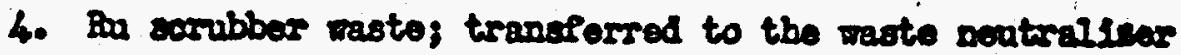
at an time before the completion of the des's wate batah.

5. I1Iteraid alurys; tranaforred to tho masto noutrallece at an time before the completion of the das's batoh. 
HDC- 1237

\section{IISTIMG OR MAJOR DOUIPWIAN PIECES}

Item

Dissolver No. 1

Dissolver No. 2

Dissolver No. 3

Small Dissolver Wolgh No. 1

Small D1ssolver Weigh bo. 2

Lerge Dissolver Welgh Ro. I

Large Dissolver Weigh No. 2

Off-gas Absorber No. 1

Off-gas Abscrber No. 2

Absorber Foed No. 1

Absorber Peed No. 2

Waste Holdup

Metal Solution No. 1

Metal Solution Ho. 2

Metal Solution No. 3

oxddizer

fiu Absorber

Oxddant Add1t,ion Tank

Centrifuge

IAP Makoup Tarik

Centrifuge Wash Tank

PH Adjustment Tank

Flitorald Slury Bold Dank

\section{Process \\ Volume}

Norkeng

Volume

1700

1700

1700

133

133

667

667

968

968

759

1820

2820

1820

1039

52.4

1260

100

25.8

120

$-14$

146

146

833

833

1065

69.2

150

Diameter Height

7.0

6.86

7.0

6.86

7.0

6.86

2.5

4.0

2.5

4.0

4.5

7.0

4.5

7.0

4.0

16.0

4.0

16.0

4.5

9.0

4.5

9.0

4.5

7.0

6.0

9.5

6.0

9.5

6.0

9.5

7.0

6.86

4.0

16.0

2.0

3.0

7.0

7.6

2.5

4.0

2.5

2.6

2.5

4.3 